\title{
Beyond Data Recovery: Developing Digital Information Systems for Cultural Resources in the Online Era - CORRIGENDUM
}

Lance K. Wollwage, Allyson Brooks, Rob Smith, Morgan McLemore, Annie Strader, and Kim Gant

DOI:10.1017/aap.2020.13, published by Cambridge University Press, June 10, 2020

In the acknowledgments section of this article (Wollwage et al. 2020) Shelby Manney's last name is misspelled. The correct last name is Manney.

\section{REFERENCE CITED}

Wollwage, Lance K., Allyson Brooks, Rob Smith, Morgan McLemore, Annie Strader, and Kim Gant

2020 Beyond Data Recovery: Developing Digital Information Systems for Cultural Resources in the Online Era. Advances in Archaeological Practice 8:253-262. 